\title{
EFFICIENCY AGAINST THE TWO-SPOTTED SPIDER MITE TETRANYCHUS URTICAE AND PREY-AGE-RELATED CHOICE OF THREE PREDATORY MITES
}

\author{
Enikő Gyuris ${ }^{1,2 *}$, Erna Szép ${ }^{1,2}$, Jenô Kontschán ${ }^{2}$, Attila Hettyey ${ }^{1}$ and Zoltán Tóth ${ }^{1}$ \\ ${ }^{1}$ Lendület Evolutionary Ecology Research Group, Plant Protection Institute \\ Centre for Agricultural Research, Hungarian Academy of Sciences \\ H-1022 Budapest, Herman Ottó út 15, Hungary \\ E-mails: gyuris.eniko@agrar.mta.hu,szep.erna1@gmail.com,kontschan.jeno@agrar.mta.hu, \\ hettyey.attila@agrar.mta.hu, toth.zoltan@agrar.mta.hu \\ ${ }^{2}$ Department of Zoology, Plant Protection Institute, Centre for Agricultural Research, Hungarian \\ Academy of Sciences, H-1022 Budapest, Herman Ottó út 15, Hungary
}

Specialist and generalist predator mites have been recommended against the two-spotted spider mite (Tetranycus urticae) as biological control agents, but their effectiveness in population regulation has been rarely examined under circumstances when prey had the opportunity to express antipredatory responses. We tested the efficiency and preference for prey life stages of three predator mites, one specialist (Phytoseiulus persimilis) and two generalists (Amblyseius swirskii and Iphiseius degenerans). We used two predator densities and performed the experiment under 'seminatural' conditions. We found that significantly less eggs and adult spider mites survived in the presence of $P$. persimilis compared to the control group, and this predator mite consumed more eggs at high density than the other predators. In the presence of $A$. swirskii fewer adult spider mites survived at low density compared to the control, whereas egg survival was lower than in the control group at both densities. In the presence of I. degenerans, only the survival of eggs was lower than in the control group and only at high density. Our results suggest that the generalist $A$. swirskii, but not $I$. degenerans, may be efficient in regulating prey populations through egg consumption, and, thus, represents an alternative to the effective specialist predator.

Key words: Phytoseiidae, biological control, two-spotted spider mite, predation effectiveness, prey preference.

\section{INTRODUCTION}

Biological control, which aims at reducing pest populations by using natural enemies (FLINT et al. 1998) is often used in integrated pest management (BALE et al. 2008). Efficiency of this approach has been boosted by the industrialized production of predators, and the resulting possibility for repeated mass release of natural enemies of pests into agricultural areas. By now, more than 230 such predator species are available for biological control world wide (VAN LeNTEREN 2012), and many of these predators can drastically decrease damage affected by pests on agricultural products (MesselinK et al. 2014). 
The two-spotted spider mite (Tetranychus urticae, Acari: Tetranychidae) is an important pest of many crops, vegetables and ornamental crop cultures in greenhouses and fields all over the world (SAbelis 1982, Helle \& SAbeLis 1985, Gerson \& Weintraub 2012). Their high reproductive potential and short generation time allow for a rapid increase in population size and quick development of resistance against insecticides (reviewed in VAN LeEUwEN et al. 2015). If their numbers are not kept below economic damage thresholds, spider mites can pose a serious threat to the production of food and ornamental crops not only by feeding, but also by transmitting various plant pathogens (Jeppson et al. 1975).

Predatory mites have been used against phytophagous spider mites for 60 years (Huffaker \& Spitzer 1951, Huffaker \& Kennett 1956, Fleschner 1959, Bravenboer \& Dosse 1962). Using specialist natural enemies as biocontrol agents was considered the most successful method for several decades (Doutt \& DeBach 1964, Parrella et al. 1999, Symondson et al. 2002). However, when new pest species, such as the western flower thrips (Frankliniella occidentalis, Pergande, Thysanoptera: Tripidae) and the whitefly (Bemisia tabaci, Gennadius, Hemiptera: Aleyrodidae), invaded Europe (van Houten et al. 1993), new biocontrol agents were needed to regulate spider mite infestations and effectively control the populations of these new pests at the same time (MCMurtry \& CROFT 1997). Since then, generalist predatory mites gradually gained an increased attention as multi-purpose biocontrol agents (MesseLINK et al. 2008, Noмiкоu et al. 2001, 2002). Besides their wider prey spectrum, generalist predator mites have several further advantages compared to specialists (JANSSEN \& SABELIS 2015), including easier and cheaper mass-rearing on alternative prey (RAMAKERS \& VAN LIEBURG 1982), the possibility of preventive release before pest abundance has become high (De KLERK \& RAMAKERS 1986, VAN RijN et al. 2002), and lower levels of both competition and cannibalism, which allows for their application at higher densities (Messelink et al. 2008, Pozzebon et al. 2015).

Several studies have investigated experimentally and compared the effectiveness of specialist and generalist predatory mites against the two-spotted spider mite (e.g. Chang \& Kareiva 1999, Symondson et al. 2002, Stiling \& Cornelissen 2005, Croft et al. 2004). Generally, these studies found that $T$. urticae abundance was lower in the presence of the specialist predator, and the population size of the specialists increased more rapidly, while the generalists remained effective for a longer period in the system. However, it is impossible to infer from these studies how specialist and generalist predatory mites regulate spider mite populations. Experiments on predator efficiency are usually carried out either in large prey populations in greenhouses (e.g. Croft \& MacRae 1992, Opit et al. 2004, Buitenhuis et al. 2015) or by observ- 
ing only a few individuals in the presence of their prey on leaf discs in the laboratory ('predator cue experiments'; e.g., ŠKaloudová et al. 2007, GrostaL \& Dicke 1999, Kriesch \& Dicke 1997). While the former may give essential information about the practical application of predator species, these studies do not allow for scrutinizing mechanisms of interactions between predators and their prey. Laboratory experiments on the other hand provide more detailed results about prey preferences and predators' foraging decisions, but different prey stages are rarely available simultaneously to the predators, and these tests do not account for the fact that under natural circumstances prey survival can be influenced by both the foraging behaviour of predators (e.g., ZHANG \& SANDERSON 1993) and the antipredator responses of the spider mites (e.g., Grostal \& Dicke 1999, Сhoн \& Takabayashi 2007).

Prey choice of predators can be crucial for the regulation of pest populations not only because predators may feed on alternative prey, but also because predators may preferentially feed on prey at a certain life-stage. Different life-stages of a species contribute differently to the overall growth of their populations, so that life-stage-dependent predation may result in varying levels of control on population growth of pest species (e.g., Cushing 1998). Furthermore, the density of predators, especially relative to the density of prey, may also have an influential effect on overall control efficiency: although high predator densities, especially in specialists, are usually associated with high consumption rates, high abundance of predators may also lead to a decrease in their effectiveness due to higher levels of attack interference, intraspecific competition, intraguild predation and cannibalism (MACRAE \& CROFT 1997, Schausberger \& Walzer 2001, Pozzebon et al. 2015). However, the effect of predator density has been rarely considered in previous studies of predation efficiency and prey preference of phytoseiid predator mites (but see JEYARANI et al. 2012).

In this study, we investigated the following question: is there any difference in prey preference and efficiency of a specialist (Phytoseiulus persimilis Athias-Henriot, 1957, Acari: Phytoseiidae) and two generalist predators ( $A$. swirskii Athias-Henriot, 1962, Acari: Phytoseiidae and I. degenerans Berlese, 1889, Acari: Phytoseiidae) at low and high predator densities? We predicted that survival of the two-spotted spider mites (Tetranychus urticae Koch, 1836, Acari: Tetranychidae) would be lowest in the presence of the specialist predator and somewhat higher when exposed to the generalists. We expected the specialist to be most effective in preying upon fully grown spider mites and the generalists to mostly prey on eggs and larvae. Finally, we predicted that the per capita efficiency of predators would be lower at higher predator densities because of interference between predators. To test these predictions we artificially infested pairs of bean plants with spider mites under laboratory 
circumstances ('seminatural conditions' henceforth), which set-up allowed us to gather detailed information about how these predator species regulate spider mite abundance. Also, while the applied setup did not enable us to assess predator-induced defences and their efficiency in spider mites, it did allow for the expression of such antipredator responses in various life stages of the prey species and, hence, these responses were allowed to take effect in the experimental system.

\section{MATERIAL AND METHODS}

Host plant - We used common bean plants (Phaseolus vulgaris Linnaeus, Fabales: Fabaceae) as host plants to maintain the stock population of spider mites in eight pots (2 beans/pot, 2-4 leaves/plant). New plants were grown from seeds every third week and kept at $15-20^{\circ} \mathrm{C}, 60 \%$ humidity and natural lighting in a plant nursery room until they reached the $2-4$ leaves stage.

Prey species - We collected spider mites (approx. 500 individuals) to start a laboratory population by placing several pots of beans for seven days into a spider mite-infested greenhouse at the Plant Protection Institute, Hungarian Academy of Sciences, Budapest, Hungary in September 2014. This population was reared for several generations on bean plants prior to the experiment. Infested plants were placed on $90 \times 40 \mathrm{~cm}$ shelves in a climate room and kept under standard climatic conditions $\left(27^{\circ} \mathrm{C} \pm 0.5^{\circ} \mathrm{C}, 60 \%\right.$ humidity, L17:D7 cycle). To provide food ad libitum, we transferred mites every 7 days to healthy bean plants by translocating infested leaves containing a few dozen mites to new plants. We transferred leaves from several infested plants to each healthy plant to allow gene flow between colonies kept on different plants. Predatory mites were purchased from a supplier before the start of the experiment and kept without food at $5^{\circ} \mathrm{C}$.

Predator mites - We tested three phytoseiid predatory mites, which are commercially available biocontrol agents (purchased from Árpád Biokontroll Ltd, Hungary) and are frequently used against the two-spotted spider mite (VAN Lenteren \& Woets 1988, Calvo et al. 2015, Vantornhout et al. 2004). Phytoseiulus persimilis is a fast moving, type I specialist predator (McMurtry \& Croft 1997, subtype Ia, see McMurtry et al. 2013) that can easily move within the spider mites' web because of adequate morphological adaptations (e.g. long dorsal setae; SABELIS \& BAKKER 1992). Amblyseius swirskii is a type III generalist predator (subtype IIIb, McMurtry et al. 2013), which can feed on several pest species and even pollen, which made it become a widely used control agent in recent years (see Calvo et al. 2015). Iphiseius degenerans is another type III generalist predator (subtype IIIc, and Type IV, see McMurtry et al. 2013) that also preys on spider mites and consumes a wide range of alternative food sources (e.g. other mites, thrips, pollen, RAMAKERs \& VoEt 1995, vaN Houten \& van Stratum 1993). Predatory mites were kept without food at $5^{\circ} \mathrm{C}$ before the start of the experiment.

Experimental design - We transferred 120 spider mite eggs to each of 35 pots with four-week old beans (5 pots/treatment, 2 beans/pot, 2-4 leaves/plant). For that, we first cut an infested leaf from the stock culture and removed all adults and surplus eggs, leaving only 120 eggs on the leaf. These leaves were then placed upside down individually on a leaf of the healthy beans. To be able to control for differences in hatching rate between pots in further statistical analyses we counted the number of emerging larvae on the fourth day. On the same day, we also placed predatory mites onto the infected beans at two densities. 
In the low density groups we added two female juvenile, i.e. larval or nymphal predatory mites directly from the commercially obtained product, whereas in the high density groups we placed five juvenile predators on each infested plant. The resulting predator: prey release ratios of ca. 1:21 and 1:52 fell within the range of ratios recommended for greenhouse-grown plantations (between 1:20 and 1:60; JANSSEN \& SABELIS 1992, OpiT et al. 2004). There were five replicate pots for each predator species at each density, resulting in 30 pots of infested beans in the treatment groups. Another five pots of infested beans lacking predators served as controls. Pots were placed in a haphazard order on five shelves in the climate chamber. They were ca. $17 \mathrm{~cm}$ apart in saucers filled with water to prevent mites from changing plants. We applied the same climatic conditions during the experiment as optimised for the stock population of spider mites (see above). During the experiment, juvenile predators matured and in some cases they laid eggs on the beans. However, as temperature and humidity were suboptimal for the development of predators and we accordingly did not find any predator larvae at the end of the experiment, we are confident that our findings are not biased by the presence of feeding predator larvae in some replicates. On the 10th day, we counted the number of spider mite eggs, juveniles (i.e. larval and nymphal stages), and adults on the beans in each replicate pot using a BTC STM-5T stereo microscope at $\times 10$ magnification. Since our experiment started with freshly emerged larval spider mites, the adults counted at the end of the experiment represented the first generation, while eggs and juveniles belonged to the second generation.

Statistical analysis - We used linear models to investigate the effect of predators on the number of each spider mite life-stage, separately at both low and high predator densities. Into these models we included the number of eggs, number of juveniles or number of adults as the dependent variable, and 'predator species' and 'number of individuals in the preceding life stage' as predictors. Preliminary analyses using linear mixed-effect models showed that the spatial position of the pots (variable 'shelf', included as a random factor) did not affect any of the measured responses (all $P>0.270$ ), thus we omitted this variable from further analyses. We fitted a linear model using generalized least squares estimation in the case of the number of eggs at high predator density due to the presence of an influential data point; with this method the resulting unequal variances among the factor levels could be specified. We used $F$-tests to estimate each predictor's significance and retained only $P \leq 0.05$ effects (if there were any) in the final models (Grafen \& HaILs 2002, ENGQvist 2005). Test statistic and $P$-value corresponding to a removed variable were obtained by adding it back to the final model. We applied Tukey HSD post-hoc tests to identify the differences between species whenever the 'predator species' predictor was found to be significant. Requirements of the fitted models were checked by plot diagnosis. All statistical analyses were carried out in R 3.2.2 (R CORE TEAM 2015) using the 'car' (Fox \& WEISBERG 2011), 'nlme' (Pinheiro et al. 2015), and 'multcomp' R packages (НотноRn et al. 2008). All tests were two-tailed with $\alpha$ set to 0.05 .

\section{RESULTS}

\section{Number of adults, eggs and juveniles at low predator density}

The number of adults was significantly affected by the presence of predators $\left(F_{3,15}=21.36, P<0.001\right)$. Specifically, the number of adults was significantly lower in the presence of $P$. persimilis than in the control group and in the 


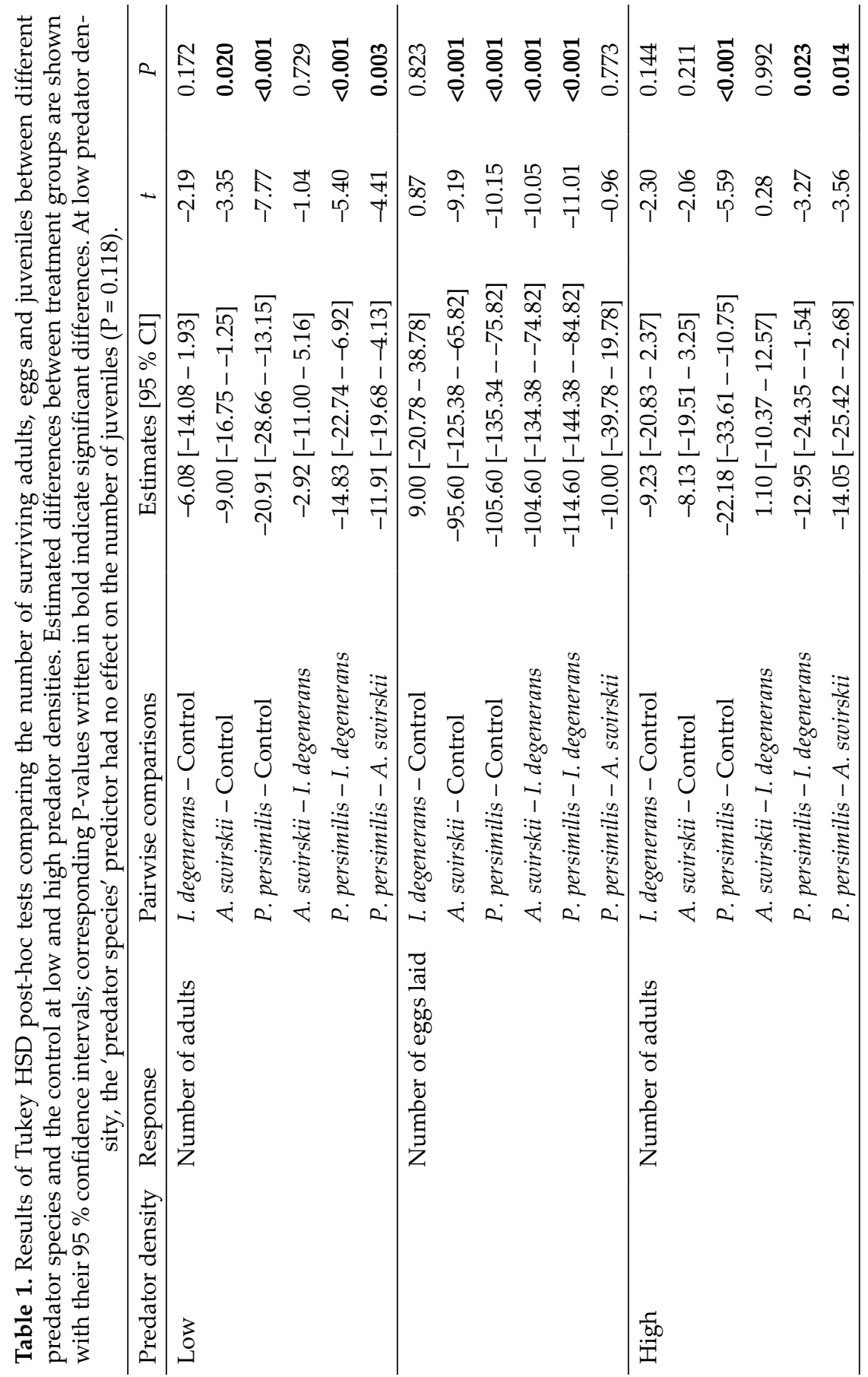




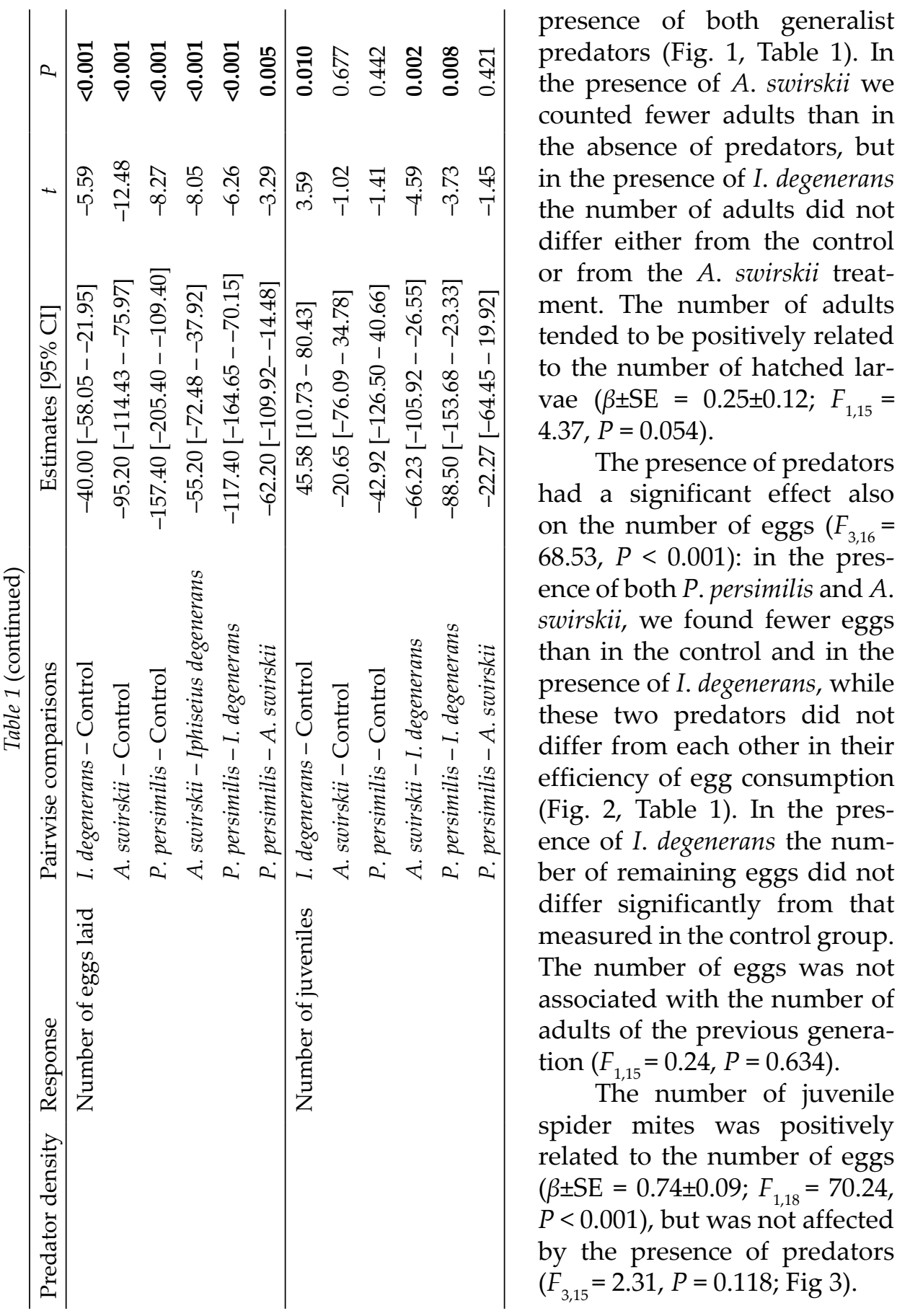


Number of adults, eggs and juveniles at high predator density

The number of adults was significantly affected by the presence of predators $\left(F_{3,16}=10.00, P=0.001\right)$ : in the $P$. persimilis group we found significantly

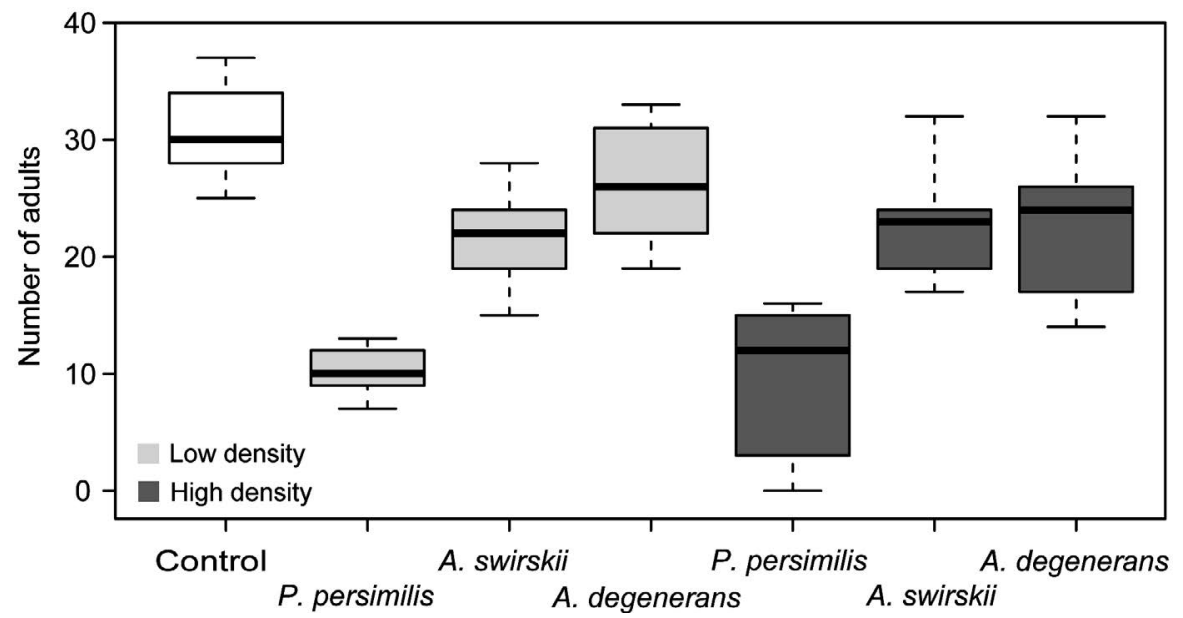

Fig. 1. Number of adult spider mites surviving in the presence of predatory mites at different predator densities. Light grey boxes represent treatments with low predator densities, dark grey boxes represent treatments with high predator densities. Boxes show the median and the 25-75 percentiles; dashed lines indicate the range

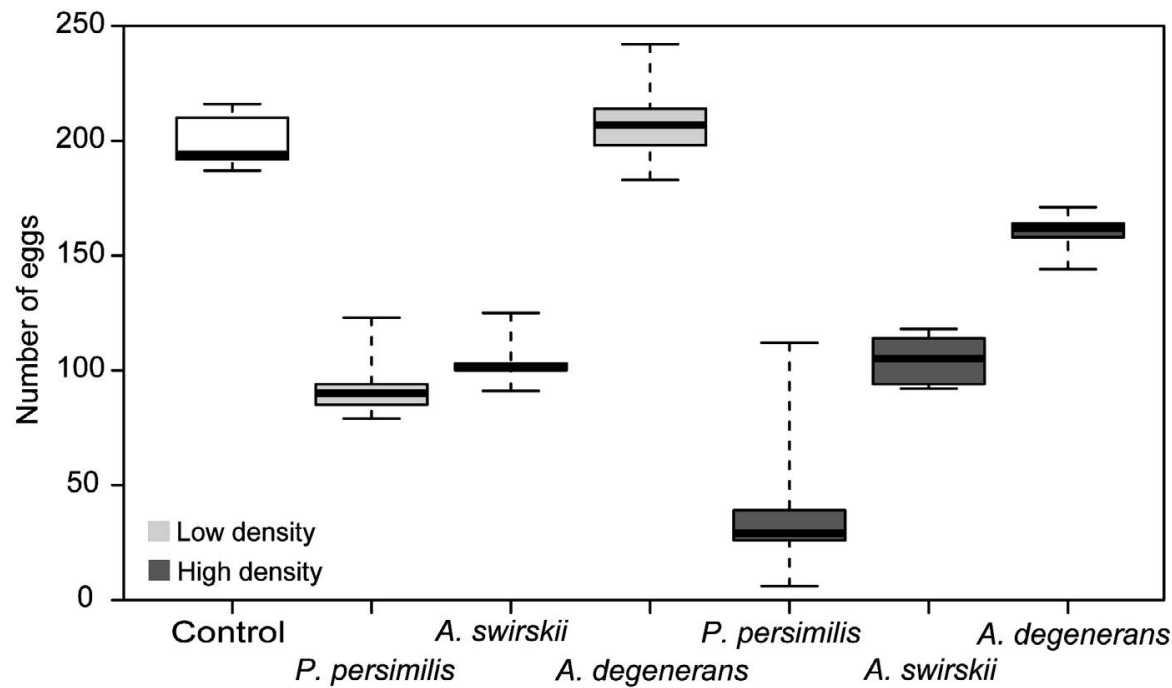

Fig. 2. Number of spider mite eggs surviving in the presence of predatory mites at different predator densities. Light grey boxes represent treatments with low predator densities, dark grey boxes represent treatments with high predator densities. Boxes show the median and the 25-75 percentiles; dashed lines indicate the range 
fewer adults than in the control group and in the presence of both generalist predators, similarly to what we found at low predator density, while the $A$. swirskii and I. degenerans groups did not differ from each other or from the control significantly (Fig. 1, Table 1). The number of adults was not related to the number of hatched larvae $\left(F_{1,15}=1.58, P=0.228\right)$.

The presence of predators had a significant effect also on the number of eggs $\left(F_{3,16}=65.17, P<0.001\right)$ : in the presence of both $P$. persimilis and A. swirskii, we counted fewer eggs than in the control or in the presence of I. degenerans. There was also a significant difference between these two predators: we found fewer eggs in the presence of $P$. persimilis than in that of A. swirskii (Fig. 2, Table 1). In the presence of I. degenerans the number of eggs was significantly lower compared to the control, but the efficiency of egg consumption did not reach that of $A$. swirskii and $P$. persimilis. The number of eggs was not related to the number of adults of the previous generation $\left(F_{1,15}=0.02, P=0.877\right)$.

The number of juvenile spider mites was significantly affected by the presence of predators $\left(F_{3,15}=14.04, P<0.001\right)$ : in the presence of I. degenerans we found more juveniles than in the presence of the other two predators or in the control (Fig. 3, Table 1). The A. swirskii and P. persimilis groups did not differ significantly from each other. The number of juveniles was positively related to the number of eggs $\left(\beta \pm S E=0.71 \pm 0.18 ; F_{1,15}=15.26, P=0.001\right)$.

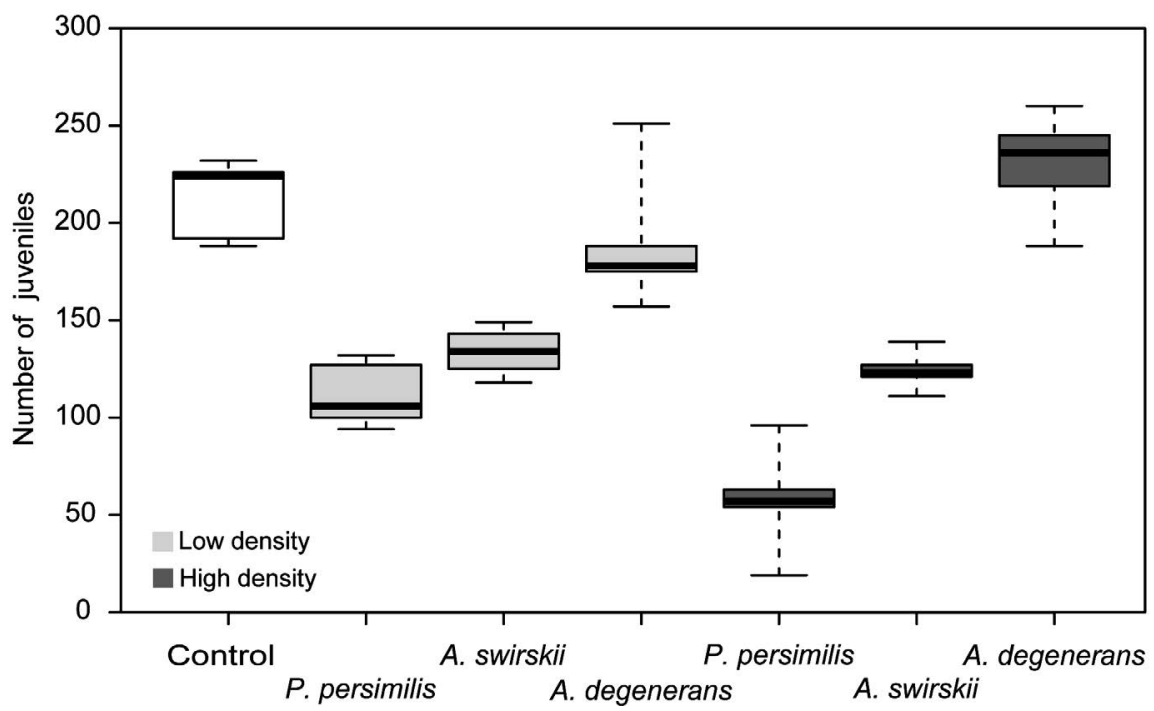

Fig. 3. Number of juvenile spider mites surviving in the presence of predatory mites at different predator densities. Light grey boxes represent treatments with low predator densities, dark grey boxes represent treatments with high predator densities. Boxes show the median and the 25-75 percentiles; dashed lines indicate the range 


\section{DISCUSSION}

In this study we compared the efficiency of three predatory mites ( $A$. swirskii, I. degenerans and $P$. persimilis) recommended for biological control against the two-spotted spider mite (T. urticae) under seminatural experimental conditions. Our results confirmed the initial prediction as the three most commonly used predators differed in their prey-age related choice and there was a positive relationship between effectiveness and predator density at least in some predator species. More specifically, we found that the specialist $P$. persimilis consumed most prey such as fewer adults and eggs survived in the presence of this predator than in the control group. In the presence of $A$. swirskii, the number of surviving eggs was significantly lower than in the control at both predator densities, but the number of surviving adult spider mites was lowered only at low predator density. In the presence of I. degenerans egg survival was lower compared to the control only at high predator density, and other life-stages of spider mites were not affected by its presence. According to these results $P$. persimilis appears to be the most effective predator of the two-spotted spider mite, while $A$. swirskii may represent a suitable alternative predator of this pest species, primarily due to its efficient egg consumption. Surprisingly, I. degenerans was found to be a rather ineffective predator under the tested conditions.

We found that prey preference was not related to the food-specificity of predators as both a specialist and a generalist species preyed on eggs and adults, but none on juveniles of the spider mite. This result partly contradicts previous findings which suggested that type I specialist predators, such as $P$. persimilis, prefer eggs, whereas the more polyphagous, generalist predators show no preference (type III generalists such as A. swirskii and I. degenerans, BlackWood et al. 2001) or prefer juvenile prey (type IV generalists, McMurtry \& CROFT 1997). This discrepancy is likely to originate from among-experiment differences in experimental set-ups: in previous studies adult spider mites were excluded from prey preference tests, and tests were conducted in small arenas, while in our study all stages of spider mites were present on an infested plant where both predators and spider mites were able to move around freely during the experiment. We have no explicit explanation for the lack of juvenile consumption in our study, but differences in movement activity, speed or sensitivity to predator kairomones between adults and juveniles and in their profitability to predators may all play a role in the observed variation in the survival of different life stages. Also, we revealed a substantial difference in prey consumption between the two type III generalist predators: $A$. swirskii consumed significantly more eggs than I. degenerans at both predator densities, thus the latter species was found to be less effective against all life-stages of spider mites. This finding is an important contribution to the 
available literature on I. degenerans, for which species information on preystage-preference and efficiency against the two-spotted spider mite, especially compared to specialists and other generalist predatory mites, is lacking.

Our results imply that the specialist $P$. persimilis, which appeared to be the most effective predator of spider mites, is capable of effectively decreasing the number of reproducing adults and eggs, thus controlling the growth of a spider mite population under the applied experimental scenario. The generalist $A$. swirskii also was found to be an efficient predator of free-ranging spider mites in our experiment despite the species being a less specialized predator of this prey. This finding accords with its successful use as a biocontrol agent in recent years against spider mites and a wide variety of other pest species in many different crops (vegetable, fruit, ornamental) and orchards (e.g., CaLvo \& Belda 2007, Gerson \& Weintraub 2012, Juan-Blasco et al. 2012). However, our results also indicate that $A$. swirskii may not quite reach the efficiency of a specialist predator against the two-spotted spider mite, and its efficiency can be increased only to a limited extent by increasing its density. In addition, we obtained this result in a set-up, where no alternative food was available to predators. Hence, under natural conditions, where a multitude of alternative prey may be present, generalists are likely to be less efficient in controlling spider mite populations, especially if an abundant alternative prey is present that is preferred by the predator (MURDoch et al. 1985, Xu \& ENKEGAARD 2010, but see Croft \& MacRae 1992).

In conclusion, we showed that predatory mites used as biocontrol agents against the two-spotted spider mite may considerably differ in predation efficiency when tested under seminatural conditions. This suggests that different experimental set-ups may be necessary to gain full detail about predators' prey preference, foraging efficiency and capacity for regulating prey populations through predator-prey interactions in species that are used as biocontrol agents. Also, our results indicated that $A$. swirskii, but not I. degenerans, may be capable of regulating free-ranging T. urticae populations through egg consumption and thus represents a good alternative to the most effective specialist predator. We propose that future studies are needed to investigate how predator-induced phenotypic responses in spider mites' morphological, behavioural and/or life-history traits may modify predators' ability to control the growth of pest populations, and how predators can retain their regulatory role across multiple generations of the prey species.

Acknowledgements - We are indebted to Márk Szederkényi for help in the laboratory and to Veronika Bókony for comments on statistics. EGy was supported by the 'Young Scientist' Programme of the Hungarian Academy of Sciences (MTA, FK-007/2015, 
2014_208_1056), JK by the Hungarian Scientific Research Fund (OTKA, K-108663), AH by the Lendület programme of the Hungarian Academy of Sciences (MTA, LP2012-24/2012) and an FP7 Marie Curie Career Integration Grant (PCIG13-GA-2013-631722), ZT by the Hungarian Scientific Research Fund (OTKA, PD108938) and the Postdoctoral Research Programme of the Hungarian Academy of Sciences (MTA, SZ-029/2013).

\section{REFERENCES}

Bale, J. S., Van Lenteren, J. C. \& Bigler F. (2008): Biological control and sustainable food production. Philosophical Transactions of the Royal Society B 363: 761-776. https://doi. org/10.1098/rstb.2007.2182

Blackwood, J. S., Schausberger, P. \& Croft, B. A. (2001): Prey-stage preference in generalist and specialist phytoseiid mites (Acari: Phytoseiidae) when offered Tetranychus urticae (Acari: Tetranychidae): eggs and larvae. - Environmental Entomology 30: 11031111. https://doi.org/10.1603/0046-225X-30.6.1103

Bravenboer, L. \& Dosse, G. (1962): Phytoseiulus riegeli Dosse als Prädator einiger Schadmilben aus der Tetranychus urticae-Gruppe. - Entomologia Experimentalis et Applicata 5: 291-304. https://doi.org/10.1111/j.1570-7458.1962.tb00594.x

Buitenhuis, R., Murphy, G., Shipp, L. \& Scott-Dupree, C. (2015): Amblyseius swirskii in greenhouse production systems: a floricultural perspective. - Experimental and Applied Acarology 65: 451-464. https://doi.org/10.1007/s10493-014-9869-9

Calvo, F. J. \& Belda, J. E. (2007): Amblyseius swirskii, un depredador para el control de mosca blanca y trips en cultivos hortı' colas. - Phytoma España 190: 58-62.

Calvo, F. J., Knapp, M., van Houten, Y. M., Hoogerbrugge, H. \& Belda, J. E. (2015): Amblyseius swirskii: What made this predatory mite such a successful biocontrol agent? - Experimental and Applied Acarology 65: 419-433. https://doi.org/10.1007/s10493-0149873-0

Chang, G. C. \& Kareiva, P. (1999): The case for indigenous generalists in biological control. Pp. 103-115. - In: Hawkins, B. A. \& Cornell, H. V. (eds): Theoretical approaches to biological control. Cambridge University Press, Cambridge. https://doi.org/10.1017/ CBO9780511542077.009

Снон, Y. \& TакавауAShi, J. (2007): Predator avoidance in phytophagous mites: response to present danger depends on alternative host quality. - Oecologia 151: 262-267. https:// doi.org/10.1007/s00442-006-0590-1

Cushing, J. M. (1998): An introduction to structured population dynamics. - CBMS-NSF Regional Conference Series in Applied Mathematics 71: 1-190. https://doi.org/10.1137/ 1.9781611970005

Croft, B. A. \& MAcRAe, I. V. (1992): Biological control of apple mites by mixed populations of Metaseiulus occidentalis (Nesbitt) and Typhlodromus pyri Scheuten (Acari: Phytoseiidae). - Environmental Entomology 21: 202-209. https://doi.org/10.1093/ee/21.1.202

Croft, B. A., Blackwood, J. S. \& McMurtry, J. A. (2004): Classifying life-style types of phytoseiid mites: diagnostic traits. - Experimental and Applied Acarology 33: 247-260. https://doi.org/10.1023/B:APPA.0000038622.26584.82

De Klerk, M. \& Ramakers, P. (1986): Monitoring population densities of the phytoseiid predator Amblyseius cucumeris and its prey after large scale introductions to control Thrips tabaci on sweet pepper. - Mededelingen van de Faculteit Landbouwwetenschappen, Rijksuniversiteit Gent 51: 1045-1048. 
Doutt, R. L. \& DeBach, P. (1964): Some biological control concepts and questions. Pp. 118-142. - In: DeBAch, P. (ed.): Biological control of insect pests and weeds. Chapman and Hall, London.

ENGQvist, L. (2005): The mistreatment of covariate interaction terms in linear model analyses of behavioural and evolutionary ecology studies. - Animal Behaviour 70: 967-971. https://doi.org/10.1016/j.anbehav.2005.01.016

Fleschner, C. A. (1959): Biological control of insect pests; insect pests are economically controlled through the utilization of their natural enemies. - Science 129: 537-544. https://doi.org/10.1126/science.129.3348.537

Flint, M. L., Dreistadt, S. H. \& CLARK, J. K. (1998): Natural enemies handbook: the illustrated guide to biological pest control. - University of California Press, California, $154 \mathrm{pp}$.

Fox, J. \& Weisberg, S. (2011): An $\{$ R $\}$ companion to applied regression. 2nd ed. - Thousand Oaks, Sage. URL: http://socserv.socsci.mcmaster.ca/jfox/Books/Companion

Gerson, U. \& Weintraub, P. G. (2012): Mites (Acari): as a factor in greenhouse management. - Annual Review of Entomology 57: 229-247. https://doi.org/10.1146/annurevento-120710-100639

Grafen, A. \& Hails, R. (2002): Modern statistics for the life science. - Oxford University Press, Oxford, $368 \mathrm{pp}$.

Grostal, P. \& Dicke, M. (1999): Direct and indirect cues of predation risk influence behavior and reproduction of prey: a case for acarine interactions. - Behavioral Ecology 10: 422-427. https://doi.org/10.1093/beheco/10.4.422

Helle, W. \& Sabelis, M. W. (1985): Spider mites: their biology, natural enemies and control. Elsevier, Amsterdam, 458 pp.

Hothorn, T., Bretz, F. \& Westfall, P. (2008): Simultaneous inference in general parametric models. - Biometrical Journal 50: 346-363. https://doi.org/10.1002/bimj.200810425

Huffaker, C. B. \& Kennett, C. E. (1956): Experimental studies on predation: Predation and cyclamen-mite populations on strawberries in California. - Hilgardia 26: 191-222. https://doi.org/10.3733/hilg.v26n04p191

Huffaker, C. B. \& Spitzer, C. H. (1951): Data on the natural control of the cyclamen mite on strawberries. - Journal of Economic Entomology 44: 519-522. https://doi.org/10.1093/ jee/44.4.519

Janssen, A. \& Sabelis, M. W. (1992): Phytoseiid life-histories, local predator-prey dynamics, and strategies for control of tetranychid mites. - Experimental and Applied Acarology 14: 233-250. https://doi.org/10.1007/BF01200566

JANSSEN, A. \& SABELIS, M. W. (2015): Alternative food and biological control by generalist predatory mites: the case of Amblyseius swirskii. - Experimental and Applied Acarology 65: 413-418. https://doi.org/10.1007/s10493-015-9901-8

Jeprson, L. R., Keifer, H. H. \& BaKer, E. W. (1975): Mites injurious to economic plants. - University of California Press, California, $528 \mathrm{pp}$.

Jeyarani, S., Singh, R. J. \& Ramaraju, K. (2012): Efficancy of predators against the two spotted spider mite, Tetranychus urticae Koch (Acari: Tetranychidae). - Journal of Biological Control 26: 279-282.

Juan-Blasco, M., Qureshi, J. A., Urbaneja, A. \& Stansly, P. (2012): Predatory mite, Amblyseius swirskii (Acari: Phytoseiidae), for biological control of asian citrus psyllid, Diaphorina citri (Hemiptera: Psyllidae). - Florida Entomologist 95: 543-551. https:// doi.org/10.1653/024.095.0302

Kriesch, S. \& Dicke, M. (1997): Avoidance of predatory mites by the two-spotted spider mite Tetranychus urticae: the role of infochemicals. - Proceedings of the Section Experi- 
mental and Applied Entomology, Netherlands Entomological Society 8: 121-126. https:// doi.org/10.1016/j.crvi.2012.02.002

MacRAe, I. V. \& CRoft, B. A. (1997): Intra-and interspecific predation by adult female Metaseiulus occidentalis and Typhlodromus pyri (Acari: Phytoseiidae): when provisioned with varying densities and ratios of Tetranychus urticae (Acari: Tetranychidae): and phytoseiid larvae. - Experimental and Applied Acarology 21: 235-246. https:// doi.org/10.1023/A:1018494804806

McMurtry, J. A. \& Croft, B. A. (1997): Life-styles of phytoseiid mites and their roles in biological control. - Annual Review of Entomology 42: 291-321. https://doi.org/10.1146/ annurev.ento.42.1.291

Mcmurtry, J. A., Moraes, G. J. D. \& Sourassou, N. F. (2013): Revision of the lifestyles of phytoseiid mites (Acari: Phytoseiidae): and implications for biological control strategies. - Systematic and Applied Acarology 18: 297-320. https://doi.org/10.11158/saa.18.4.1

Messelink, G.J., Bennison, J., Alomar, O., Ingegno, B. L., Tavella, L., Shipp, L., Palevsky, E. \& WëCKERS, F. L. (2014): Approaches to conserving natural enemy populations in greenhouse crops: current methods and future prospects. - BioControl 59: 377-393. https://doi.org/10.1007/s10526-014-9579-6

Messelink, G. J., van Maanen, R., van Steenpaal, S. E. \& Janssen, A. (2008): Biological control of thrips and whiteflies by a shared predator: two pests are better than one. Biological Control 44: 372-379. https://doi.org/10.1016/j.biocontrol.2007.10.017

Murdoch, W. W., Chesson, J. \& Chesson, P. L. (1985): Biological control in theory and practice. - The American Naturalist 125(3): 344-366. https://doi.org/10.1086/284347

Nomikou, M., Janssen, A., Schraag, R. \& Sabelis, M. W. (2001): Phytoseiid predators as potential biological control agents for Bemisia tabaci. - Experimental and Applied Acarology 25: 271-291. https://doi.org/10.1023/A:1017976725685

Nomikou, M., Janssen, A., Schraag, R. \& Sabelis, M. W. (2002): Phytoseiid predators suppress populations of Bemisia tabaci on cucumber plants with alternative food. - Experimental and Applied Acarology 27: 57-68. https:/doi.org/10.1023/A:1021559421344

Opit, G. P., Nechols, J. R. \& Margolies, D. C. (2004): Biological control of two-spotted spider mites, Tetranychus urticae Koch (Acari: Tetranychidae), using Phytoseiulus persimilis Athias-Henriot (Acari: Phytoseidae): on ivy geranium: assessment of predator release ratios. - Biological Control 29: 445-452. https://doi.org/10.1016/j.biocontrol.2003.08.007

Parrella, M. P., Hansen, L. S. \& Van Lenteren, J. C. (1999): Glasshouse environments. Pp. 819-839. - In: Bellows, T. S. \& Fisher, T. W. (eds): Handbook of biological control: principles and applications of biological control. Academic Press, San Diego. https://doi. org/10.1016/B978-012257305-7/50078-3

Pinheiro, J., Bates, D., DebRoy, S. \& Sarkar, D. (2015): R Core Team. nlme: Linear and nonlinear mixed effects models. R package version 3.1-122. http://CRAN.R-project. org/package $=$ nlme

Pozzebon, A., Loeb, G. M. \& Duso, C. (2015): Role of supplemental foods and habitat structural complexity in persistence and coexistence of generalist predatory mites. - Scientific Report 5: 14997. https://doi.org/10.1038/srep14997

R Core Team (2015): R: A language and environment for statistical computing. Vienna: R Foundation for Statistical Compution. http://www.Rproject.org. 
Ramakers, P. \& van Lieburg, M. (1982): Start of commercial production and introduction of Amblyseius mckenziei Sch. and Pr. (Acarina: Phytoseiidae): for the control of Thrips tabaci Lind. (Thysanoptera: Thripidae): in glasshouses. - Mededelingen van de Faculteit Landbouwwetenschappen, Rijksuniversiteit Gent 47: 541-545.

Ramakers, P. M. J. \& Voet, S. J. P. (1995): Use of castor bean Ricinus commutes for the introduction of the thrips predator Amblyseius degenerans on glass house-grown sweet pepper. - Mededelingen van de Faculteit Landbouwwetenschappen, Rijksuniversiteit Gent 60: 885-891.

SABELIS, M. W. (1982): Biological control of two-spotted spider mites using phytoseiid predators. Dissertation, Agricultural University, Wageningen, $242 \mathrm{pp}$.

SAbelis, M. W. \& BAKKer, F. M. (1992): How predatory mites cope with the web of their tetranychid prey: a functional view on dorsal chaetotaxy in the Phytoseiidae. $-E x$ perimental and Applied Acarology 16: 203-225. https://doi.org/10.1007/BF01193804

Schausberger, P. \& Walzer, A. (2001): Combined versus single species release of predaceous mites: predator-predator interactions and pest suppression. - Biological Control 20: 269-278. https://doi.org/10.1006/bcon.2000.0908

ŠKaloudová, B., Zemek, R. \& Ǩ̌ıIVAn, V. (2007): The effect of predation risk on an acarine system. - Animal Behaviour 74: 813-821. https://doi.org/10.1016/j.anbehav.2007.02.005

Stenseth, C. (1979): Effect of temperature and humidity on the development of Phytoseiulus persimilis and its ability to regulate populations of Tetranychus urticae (Acarina: Phytoseiidae. Tetranychidae). - Entomophaga 24: 311-317. https://doi.org/10.1007/ BF02374246

Stiling, P. \& Cornelissen, T. (2005): What makes a successful biocontrol agent? A meta-analysis of biological control agent performance. - Biological Control 34: 236-246. https://doi.org/10.1016/j.biocontrol.2005.02.017

Symondson, W. O. C., Sutherland, K. D. \& Greenstone, M. H. (2002): Can generalist predators be effective biocontrol agents? - Annual Review of Entomology 47: 561-594. https://doi.org/10.1146/annurev.ento.47.091201.145240

van Houten, Y. M. \& Van Stratum, P. (1993): Biological control of western flower thrips in sweet peppers using non-diapausing predatory mites. - International Organisation for Biological Control - West Palaearctic Regional Section. Bulletins 16: 77-80.

Van Leeuwen, T., Tirry, L., Yamamoto, A., Nauen, R. \& Dermauw, W. (2015): The economic importance of acaricides in the control of phytophagous mites and an update on recent acaricide mode of action research. - Pesticide Biochemistry Physiology 121: 12-21. https://doi.org/10.1016/j.pestbp.2014.12.009

VAN LENTEREN, J. C. (2012): The state of commercial augmentative biological control: plenty of natural enemies, but a frustrating lack of uptake. - BioControl 57: 1-20. https://doi. org/10.1007/s10526-011-9395-1

Van Lenteren, J. C. \& Woets J. V. (1988): Biological and integrated pest control in greenhouses. - Annual Review of Entomology 33: 239-269. https://doi.org/10.1146/annurev. en.33.010188.001323

van Rijn, P. C., van Houten, Y. M. \& Sabelis, M. W. (2002): How plants benefit from providing food to predators even when it is also edible to herbivores. - Ecology 83: 2664-2679. https://doi.org/10.1890/0012-9658(2002)083[2664:HPBFPF]2.0.CO;2

Vantornhout, I., Minnaert, H. L., Tirry, L. \& De Clerce, P. (2004): Effect of pollen, natural prey and factitious prey on the development of Iphiseius degenerans. - BioControl 49: 627-644. https://doi.org/10.1007/s10526-004-5280-5 
Xu, X. \& EnkegaARd, A. (2010): Prey preference of the predatory mite, Amblyseius swirskii between first instar western flower thrips Frankliniella occidentalis and nymphs of the two-spotted spider mite Tetranychus urticae. Journal of Insect Science 10: 1-11. https://doi.org/10.1673/031.010.14109

ZHANG, Z. Q. \& SANDERSON J. P. (1993): Spatial scale of aggregation in three acarine predator species with different degrees of polyphagy. Oecologia 96: 24-31. https://doi. org/10.1007/BF00318026

Received February 1, 2017, accepted July 29, 2017, published March 30, 2018 